\title{
Confronting the threat of SARS-CoV-2: Realities, challenges and therapeutic strategies (Review)
}

\author{
RUIXUE WANG ${ }^{1}$, XIAOSHAN LUO $^{2}$, FANG LIU $^{1}$ and SHUHONG LUO ${ }^{2}$ \\ Departments of ${ }^{1}$ Basic Medicine and Biomedical Engineering and ${ }^{2}$ Laboratory Medicine, \\ School of Stomatology and Medicine, Foshan University, Foshan, Guangdong 528000, P.R. China
}

Received August 1,2020; Accepted November 2, 2020

DOI: $10.3892 /$ etm.2020.9587

\begin{abstract}
The novel coronavirus (SARS-CoV-2) appeared in2019 in Wuhan, China, and rapidly developed into a global pandemic. The disease has affected not only health care systems and economies worldwide but has also changed the lifestyles and habits of the majority of the world's population. Among the potential targets for SARS-CoV-2 therapy, the viral spike glycoprotein has been studied most intensely, due to its key role in mediating viral entry into target cells and inducing a protective antibody response in infected individuals. In the present manuscript the molecular mechanisms that are responsible for SARS-CoV-2 infection are described and a progress report on the status of SARS-CoV-2 research is provided. A brief review of the clinical symptoms of the condition and current diagnostic methods and treatment plans for SARS-CoV-2 are also presented and the progress of preclinical research into medical intervention against SARS-CoV-2 infection are discussed.
\end{abstract}

Correspondence to: Dr Shuhong Luo, Department of Laboratory Medicine, School of Stomatology and Medicine, Foshan University, 5 Hebin Road, Chancheng, Foshan, Guangdong 528000, P.R. China E-mail:sluo815@gmail.com

Dr Fang Liu, Department of Basic Medicine and Biomedical Engineering, School of Stomatology and Medicine, Foshan University, 5 Hebin Road, Chancheng, Foshan, Guangdong 528000, P.R. China E-mail: 870247953@qq.com

Abbreviations: ACE2, angiotensin-converting enzyme 2; COVID-19, coronavirus disease 2019; IL-6, interleukin-6; LH, Lianhua qingwen; MERS-COV, Middle East respiratory syndrome coronavirus; RBD, receptor-binding domain; SARS, severe acute respiratory syndrome; SARS-CoV-2, severe acute respiratory syndrome coronavirus 2 TMPRSS2, transmembrane protease serine 2

Key words: coronavirus disease 2019, COVID-19, severe acute respiratory syndrome coronavirus 2

\author{
Contents \\ 1. Introduction \\ 2. Virology \\ 3. Epidemiology \\ 4. Mechanism of SARS-CoV-2 infection \\ 5. Clinical manifestations and diagnosis \\ 6. Treatments \\ 7. Vaccines \\ 8. Conclusions and outlook
}

\section{Introduction}

Following the emergence of severe acute respiratory syndrome (SARS) coronavirus (SARS-CoV) in 2003 and Middle East respiratory syndrome coronavirus (MERS-CoV) in 2012, a novel coronavirus pneumonia epidemic, named COVID-19 by the World Health Organization (WHO) (1), resulted from SARS-CoV-2 infection in Wuhan, China, and was identified in late December 2019 (2). Subsequently, this disease spread rapidly to all parts of the world. As the number of patients with SARS-CoV-2 infection increased globally, the WHO declared COVID-19 a pandemic on 12th March 2020 (3). To date $>37$ million people have contracted this disease and as of 10th October 2020, the death toll stands at $>1,070,355$ (4).

SARS-CoV-2 is a member of the nested viroid family cornonaviridae and the coronavirus genus. It is the 7 th coronavirus known to infect humans and the third coronavirus known to be transmitted from animal to animal, animal to human and human to human $(5,6)$. COVID-19 has been suggested to be a disease of the nicotinic cholinergic system (7) and SARS-CoV-2 most commonly causes a lower respiratory infection or pneumonia (8). High levels of mortality are noticed in elderly individuals infected with SARS-CoV-2, with the risk of death in individuals aged $<65$ years 15 to 100 fold lower compared with that in older individuals in developed countries, including Germany, Canada, France, Italy and the USA (9). Oxidative stress and inflammatory cytokine production in elderly individuals cause a chronic low level of inflammation and increase the severity of viral infections (10). In view of the adverse consequences of the current COVID-19 epidemic, it is necessary to develop effective treatment strategies to deal with the lack of effective drugs, high mortality 
and the possibility of further epidemics caused by the virus. The present manuscript describes the situation, clinical characteristics and current detection and treatment methods for SARS-CoV-2 infection and discusses the developing strategies for the treatment of COVID-19.

\section{Virology}

The first strain of SARS-CoV-2 was isolated from Wuhan, China on 24th January 2020 after the outbreak of COVID-19 (11). In similarity to other coronaviruses, SARS-CoV-2 consists of four structural proteins, namely the spike (S), envelope, membrane/ matrix (M) and nucleocapsid proteins (12). Non-structural proteins are produced after RNA genome expression in the host cell during formation of new virus particles (12). On the surface of mature coronavirus, the S protein usually forms a crown-like trimer, an important morphological feature which differentiates coronaviruses from other viruses (11). Similarly, SARS-CoV-2 viruses isolated in South Korea have also been identified by typical corona-like structure formed by the S protein (13).

Based on phylogenetic analysis [Global Initiative on Sharing AllInfluenza Data (GISAID) accession no.EPI_ISL_402124] (14), SARS-CoV-2 is a lineage B betacoronavirus and shares high sequence identity with SARS-CoV and the bat SARS-like coronavirus (SL-CoV) (15). Like MERS-CoV and SARS-CoV, SARS-CoV-2 is a positive-sense single-stranded RNA virus and shows a similar pattern of infection (16). Using full-length genome sequencing, SARS-CoV-2 and a bat coronavirus BatCoV RaTG13 were found to be $96 \%$ identical (14), suggesting an origin of the SARS-CoV-2 infection in bats. Comprehensive sequence analysis with relative synonymous codon usage bias demonstrated that SARS-CoV-2 may be derived from recombination between a bat coronavirus and another coronavirus from snakes (17). Additionally, mink have been suggested as a potential host of SARS-CoV-2 (18). Interspecies transmissions of viruses between animals and humans may result in unpredictable pathogenic potential and transmissible COVID-19 disease (19).

\section{Epidemiology}

A cluster of patients with atypical pneumonia was reported in Wuhan, China on December 31, 2019 (20). During the subsequent 6 weeks, several cases were reported in more than 37 countries, including the USA, Japan, Iran and South Korea (1). The infection rapidly spread across the globe, threatening global public health. Chinese authorities locked-down Wuhan city and suspended transport to and from Wuhan to control the spread (21). Imposing mobility restrictions as fast as possible is thought to be an effective way to avoid an outbreak (22). Numerous patients were diagnosed and treated, and the epidemic situation in China has been gradually controlled (23). Various countries have instituted measures, such as practicing good hygiene (washing hands), wearing a mask and quarantine (24). Meanwhile, understanding of the epidemiological characteristics of COVID-19 have developed and immunotoxicity of chemicals and drugs and immunodeficiency caused by the environment and lifestyle are thought to contribute to COVID-19 (24). Nevertheless, uncertainties remain regarding both the virus-host interaction and the evolution of the epidemic, leaving the epidemic situation worldwide severe.

\section{Mechanism of SARS-CoV-2 infection}

The SARS-Cov-2 virus binds to the angiotensin-converting enzyme 2 (ACE2) on human cells via the receptor binding domain (RBD) located on the S1 subunit of the $\mathrm{S}$ protein-homotrimer of the $\mathrm{S}$ protein (25). This leads to clathrin-mediated endocytosis $(26,27)$, release of viral RNA and induction of viral replication. The viral genome codes for non-structural proteins containing polyproteins, nucleoproteins, RNA polymerase, 3-chymotrypsin-like protease, papain-like protease and helicase in the host cell in order to form new virus particles (12). The newly manufactured virus emerges via exocytosis where it binds again to ACE2, thus entering a vicious cycle of infecting other cells (12).

As a glycoprotein, the $\mathrm{S}$ protein is generally composed of 1,160-1,400 amino acid residues and contains multiple $\mathrm{N}$-glycosylation sites, which are important for proper folding and modulating accessibility to host proteases. The $\mathrm{S}$ protein exists in a metastable prefusion conformation, where the S1 and S2 subunits remain noncovalently bound in the prefusion conformation (28). The S1 subunit, comprising the RBD on the surface, is responsible for recognizing and binding to the receptor of the host cell. The S2 subunit, embedded in the envelope, mediates membrane fusion during viral assembly (29). It has been proposed that the $S$ protein is activated for membrane fusion via extensive irreversible conformational changes $(30,31)$. When the $\mathrm{S} 1$ subunit binds to a susceptible cell receptor, S1/S2 cleavage is triggered, which enables the S1 RBD to undergo hinge-like conformational movements and the S2 subunit transits to a highly stable post fusion conformation. This S1/S2 cleaved site harbors several arginine residues, rendering it multibasic (32). SARS-CoV-2 $\mathrm{S}$ harbors a furin cleavage site (33), a feature conserved among the 144 SARS-CoV-2 isolates sequenced to date, but not found in the closely related bat virus RaTG13 S (14), at the $\mathrm{S} 1 / \mathrm{S} 2$ boundary, which is processed during biosynthesis. It can be hypothesized that the almost ubiquitous expression of furin-like proteases participates in expanding SARS-CoV-2 cell and tissue tropism, relative to SARS-CoV, and increases viral transmissibility and/or alters its pathogenicity.

Proteases are necessary for host cell entry and promoting virus-cell fusion $(32,34)$. When SARS-CoV-2 targets host cells (13), the serine protease transmembrane protease serine 2 (TMPRSS2) is employed for $\mathrm{S}$ protein priming (Fig. 1) $(12,32,35)$. Notably, all ACE2-expressing pulmonary cells are also TMPRSS2-positive (35).

Similarly to SARS-CoV infection, the $\mathrm{S}$ protein of SARS-CoV-2 binds to the human ACE2 receptor, which partially explains the efficient transmission of SARS-CoV-2 in humans (34). The binding ability of SARS-CoV-2 S protein to ACE2 is stronger than that of SARS-CoV (36), which may explain why SARS-CoV-2 is more transmissible than SARS-CoV. The expression level and tissue distribution of ACE2 determine the cell tropism and pathogenicity of SARS-CoV-2 (37). Coronavirus infection and the induced cytokine storm are able to enhance the expression of ACE2 in host cells, further accelerating infection and transmission of the virus (38). The expression of ACE2 in human lung cells was analyzed using single cell RNA sequencing analysis technology and the results indicated that the expression of ACE2 


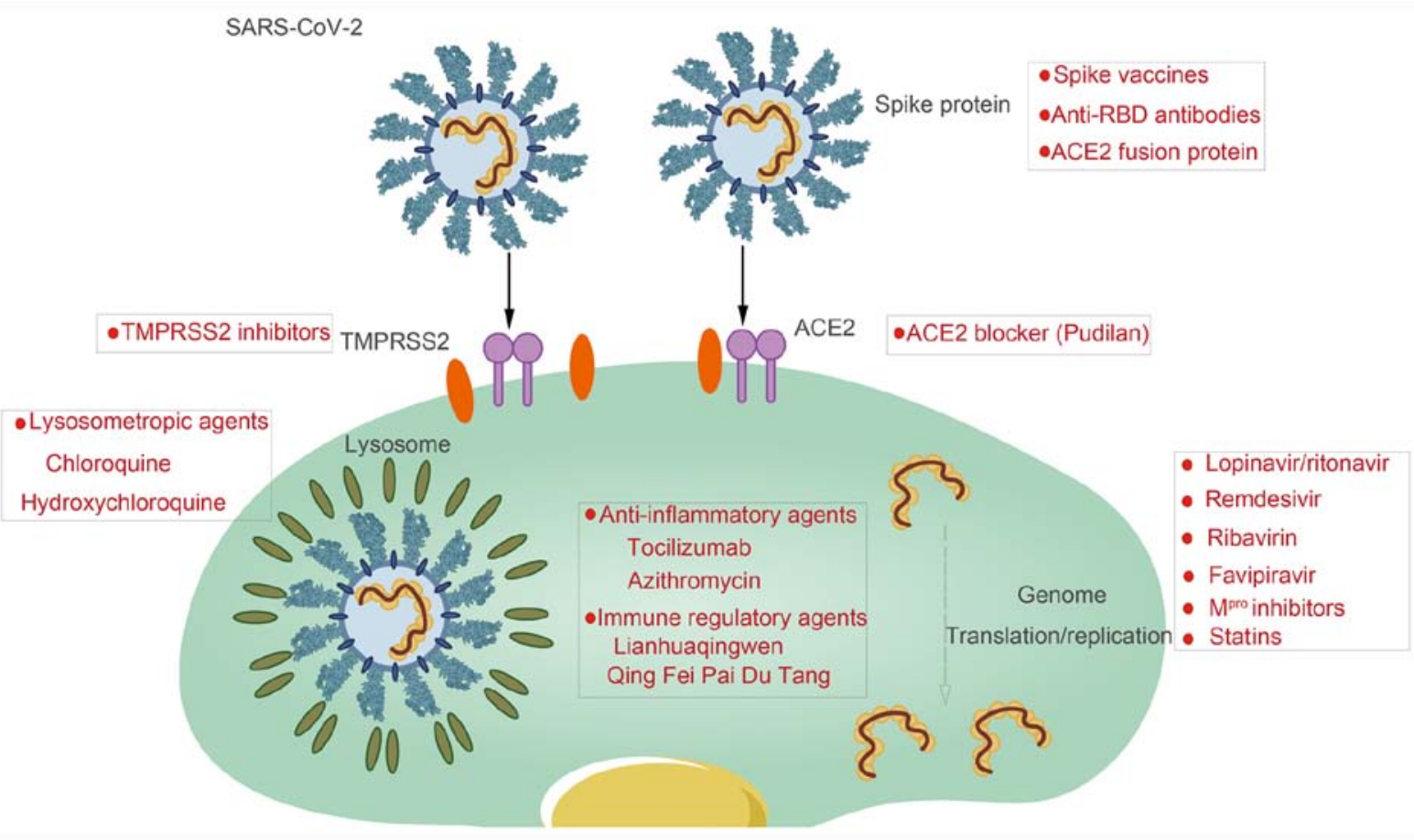

Figure 1. Mechanism by which SARS-CoV-2 infects host cells. The S protein on the surface of the SARS-CoV-2, a newly emerged pathogen spreading worldwide, binds with high affinity to the human ACE2 receptor to gain entry into target cells, including those of lung and gastrointestinal tissues. SARS-CoV-2 employs the serine protease TMPRSS2 for S protein priming. The pharmaceutical agents which disrupt the COVID-19 infection of host cells are exhibited in red based on the mechanism and the specific site of action. SARS-CoV-2, severe acute respiratory syndrome coronavirus 2; ACE2, angiotensin-converting enzyme 2; TMPRSS2; transmembrane protease serine 2; S, spike; COVID-19, coronavirus disease 2019; RBD, receptor binding domain.

was concentrated in a small group of type II alveolar epithelial cells in the lung (37), suggesting that these cells may be the target of SARS-CoV-2. Recent studies have also indicated that ACE2 is highly expressed not only in lung cells, esophageal epithelium and stratified epithelial cells, but also in the absorbing intestinal epithelial cells of the ileum and colon (39), suggesting that the digestive system is also a potential pathway for SARS-CoV-2 infection.

\section{Clinical manifestations and diagnosis}

Clinical manifestations. The most frequent clinical feature in patients infected with SARS-CoV-2 appears to be pneumonia. Early COVID-19 is characterized primarily by the symptoms of fever, myalgia, cough and sore throat, all of which are common in other acute respiratory virus infections (8). Most cases appear to be mild, and most hospitalized patients have pneumonia with bilateral infiltration upon chest imaging $(8,40)$. Notably, the period from infection to the appearance of symptoms varies in patients with SARS-CoV-2 infection, and there are also great differences in symptoms among individuals (41). There are patients with COVID-19 with no detectable fever or other clinical symptoms (5).

SARS-CoV-2 is believed to be transmitted through large respiratory droplets and close contact. Positive reverse transcription (RT-PCR) results from stool specimens from patients with COVID-19 suggested that stool or sewage might serve as another vehicle for viral transmission (42).

PCR detection. Currently, the preferred method for detection of COVID-19 is via molecular testing. Multiple specimen types are recommended due to the unknown sensitivity and specificity of tests. The PCR detection method was designed to detect a variety of targets in SARS-CoV-2 genome and is the most widely used molecular diagnostic method to analyze samples such as sputum, nasal swab, pharyngeal swab, bronchoalveolar lavage and blood plasma $(43,44)$. A significant portion of suspected patients who have tested negative for viral RNA indeed fit the diagnosis based on clinical and chest CT findings (45). PCR detection involves RNA extraction and preservation, and the degradation and contamination of RNA samples could result in missed detection or false positive results (46). Moreover, the time, manpower and economic (advanced PCR equipment and expensive reagents) costs are such that it is difficult to meet the huge testing demand in the rapid outbreak of COVID-19 (45).

Serological tests. Serological testing is method that is considered, at the present time, as complementary to nucleic acid detection (47). IgM testing has been designed and validated, but currently limited information is available about the performance of these tests (48). Some tests may produce inaccurate results (49), suggesting gold immunochromatography assay and ELISA methods should be used to eliminate or reduce the impact of cross-reaction. Serological testing is helpful for preliminary screening of suspected and high-risk groups (50).

Previously, numerous methods for rapid detection and diagnosis of coronavirus infection based on the $\mathrm{S}$ protein have been developed. Thachil et al (51) established an indirect ELISA with the S1 subunit of the S protein of porcine delta coronavirus as the coating antigen, with a sensitivity of $91 \%$ and specificity of $95 \%$ that was able to detect the specific IgG 
specific antibody against porcine delta coronavirus in serum samples. Zhao et al (52) established a set of ELISA detection methods for antibodies against the S1 subunit of horse coronavirus, which effectively diagnoses infection. Moreover, Sunwoo et al (53) developed a bispecific monoclonal antibody against the S1 antigen on the surface of SARS-CoV, which can be used in clinical diagnosis of suspected SARS patients. Since the $S$ protein is the most important antigenic determinant for coronavirus (54), ELISA methods based on the $S$ protein antigen-antibody reaction could be effective. Additionally, ELISA detection is much faster and easier in comparison with PCR detection (46). Therefore, developing an effective ELISA kit for SARS-CoV-2 detection would be helpful in the current epidemic.

\section{Treatment}

Overview. Numerous compounds have been proven effective against SARS-CoV and MERS-CoV which have not been tested widely for the newly emerged SARS-CoV-2. At present, drugs that inhibit the process of virus replication, assembly and fusion with host cells are under research.

Lopinavir/ritonavir. Lopinavir/ritonavir, protease inhibitors that have been widely used for the treatment of human immunodeficiency virus-1 infection (55), are usually used in combination with azithromycin to increase the half-life of lopinavir by inhibiting cytochrome P450. A previous study suggested that patients with SARS treated with a combination of lopinavir/ritonavir and ribavirin had lower risk of developing acute respiratory distress syndrome or death (56). The combination of lopinavir/ritonavir and interferon- $\beta$ improved outcomes in MERS-CoV infection (57). However, the lopinavir/ritonavir combination provided little benefit in improving the clinical outcomes in patients with mild and moderate COVID-19 (58). There were no benefits of lopinavir/ritonavir beyond the standard treatment in a trial performed on patients with severe COVID-19 in China, but a slightly lower number of deaths was observed in the group receiving lopinavir/ritonavir in the late stage of SARS-CoV-2 infection compared with the standard-treatment group (59).

Remdesivir. As a new nucleoside analogue $(60,61)$, remdesivir has a broad-spectrum antiviral capacity against filoviruses, paramyxoviruses, pneumoviruses, and human and bat derived coronaviruses (62-65), which makes it a promising agent for COVID-19 treatment. Against the Ebola virus, remdesivir has completed the phase I clinical trial, and the pharmacokinetics and safety in the human body have relatively complete data (66). A study reported that the replication of virus in human primary cell was significantly inhibited $(67,68)$, because the triphosphate cannot be removed by non-structural protein $14 \mathrm{~N}$-terminal exoribonuclease (69). Remdesivir effectively reduced the virus titer in the lungs of rhesus macaques infected with MERS-CoV and it improved the degree of lung tissue damage in comparison with that of the control group (70). New England Journal of Medicine recently published a case of SARS-CoV-2 infection in the United States treated with remdesivir (71). A patient infected with SARS-CoV-2 was administered remdesivir and the clinical status improved within $24 \mathrm{~h}$ without any noticeable adverse effect (71). It is worth noting that uncertainties about adverse effects and clinical efficacy of remdesivir have been reported recently, such as nausea, vomiting, rectal hemorrhaging and hepatic toxicity (72).

Favipiravir. Favipiravir, which selectively and potently inhibits RNA-dependent RNA polymerase (73-75), has been administrated to patients infected with Ebola virus (76) and has been approved in Japan for influenza treatment and in China for the treatment of COVID-19 (77). Preliminary studies on 80 patients with COVID-19 in China have demonstrated that favipiravir exerts an antiviral action more potent than lopinavir/ritonavir, and no serious adverse reactions have been reported (77).

Chloroquine and hydroxychloroquine. The antimalarial drugs chloroquine and hydroxychloroquine are used in Korea and China for the treatment of COVID-19 $(78,79)$. Chloroquine presented an encouraging anti-SARS-CoV-2 profile in early clinical trials $(68,80)$. Additionally, the chloroquine hydroxyl derivative hydroxychloroquine (available as an antirheumatic drug under the name 'Plaquenil') demonstrated a stronger in vitro anti-COVID-19 effect than chloroquine $(81,82)$. A study found no evidence of clinical benefit of the combination of hydroxychloroquine and azithromycin for the treatment of 11 patients with severe COVID-19 (83). However, patients with COVID-19 in France treated with hydroxychloroquine (600 mg per day) were significant improved, even in combination with azithromycin (84). In the wake of this evidence, hydroxychloroquine was included in guidelines for COVID-19 therapy in Belgium (85) and Italy (86). Recently, chloroquine was found not to inhibit human lung cancer cells infection with SARS-CoV-2 although this study used human lung epithelial cells, not the renal cell line selected in previous experiments with TMPRSS2 protease (87). However, chloroquine/hydroxychloroquine has an antiviral effect because there is another enzyme, cathepsin L (catl), in renal cells that can process the $\mathrm{S}$ protein of the novel coronavirus, and its function is affected by cell $\mathrm{pH}$ (87). Chloroquine/hydroxychloroquine limits the function of catl by regulating $\mathrm{pH}$, thus indirectly inhibiting the invasion of SARS-CoV-2 (87). Moreover, a study from French scientists indicated that hydroxychloroquine cannot reduce viral load nor improve clinical symptoms, prevent or treat COVID-19, regardless of the dosage and timing (88). Thus, the application of chloroquine/hydroxychloroquine requires further study.

Tocilizumab. When COVID-19 progresses from severe to critical, patients may develop a cytokine storm immune reaction. Consequently, the treatment of the cytokine storm is an important part of rescuing severe patients (89). Since interleukin-6 (IL-6) is one of the key cytokines involved in infection-induced cytokine storm, an IL-6 receptor (IL-6R) antagonist would be a promising drug for patients with COVID-19. Tocilizumab, a monoclonal antibody with activity against the IL-6R was developed for the treatment of rheumatoid arthritis (90) and has been approved by the US FDA for the treatment of cytokine release syndrome (91). For COVID-19, it has been tested on 6 patients in Italy who experienced rapid improvement in their health only $24-48 \mathrm{~h}$ after administration (92). As 
tocilizumab blocks the IL-6-mediated immune response in COVID-19, it was approved to treat pneumonia and the severe cytokine release syndrome induced by the immune system in patients with coronavirus as an 'off label' usage in China (93).

Dexamethasone. Dexamethasone, a synthetic glucocorticoid with anti-inflammatory and immunosuppressive properties, inhibits growth of myeloma and lymphoma cells (94). Upon binding to the glucocorticoid receptor, a ligand activated transcription factor, dexamethasone regulates the expression of a diverse sets of genes, resulting in resolution of inflammation. Dexamethasone inhibits the activity of inflammatory cells, including neutrophils, macrophages and lymphocytes, and suppresses pro-inflammatory cytokines, such as tumor necrosis factor (TNF) and interleukins, and other genes such as cyclooxygenase-2 and inducible nitric oxide synthase (95).

A randomized, controlled clinical trial in the United Kingdom found that dexamethasone reduced deaths by about one-third in patients with COVID-19 who were on ventilators (96). Administered at a low-to-moderate dose of $6 \mathrm{mg}$ dexamethasone per day for 10 days improved the clinical outcomes in patients on ventilators (96). Those who were receiving oxygen therapy but were not on ventilators also saw improvement, but no effect on patients who were not receiving oxygen therapy or ventilation was observed. Some reports suggested that well-timed, higher doses of $0.5-1.0 \mathrm{mg} / \mathrm{kg}$ methylprednisolone per day improved outcomes in those patients with respiratory failure, severe illness, and cytokine storm $(97,98)$. Notably, steroidal drugs can be associated with numerous adverse effects, including diabetes/hyperglycemia, osteopenia, cataracts, avascular necrosis, fluid retention, hypertension and infection $(94,99)$. A meta-analysis of 15 studies with 5,270 patients with SARS-CoV-2 indicated that corticosteroids were associated with higher rates of bacterial infection, longer hospital stay and higher mortality (100). These reports suggest that high-dose steroidal agents may be beneficial in later stages of severe SARS-CoV-2 infection and/or impending cytokine storm $(94,99)$. Therefore, patients with non-severe, non-cytokine storm SARS-CoV-2 infection are not recommended for dexamethasone treatment, and the possible side effects of dexamethasone drug used must be considered.

Traditional Chinese medicine (TCM). Lianhua Qingwen (LH), is produced from a mixture of herbs, including Forsythia suspensa, Lonicera japonica Thunberg, Ephedra sinica, Prunus armeniaca, Isatis indigotica, Dryopteridis crassirhizoma, Houttuynia cordata, Pogostemon cablin, Rhodiola rosea and Glycyrrhiza inflanta, along with menthol and a traditional Chinese mineral medicine containing calcium sulfate, Gypsum Fibrosum. LH is used to treat influenza and chronic obstructive pulmonary disease (101). Patients with influenza complicated by bronchial pneumonia that received LH capsules displayed greater symptom improvement than those in a control group (101). A prospective multicenter open-label, randomized, controlled trial of LH in 284 patients with COVID-19 (142 each in the treatment and control groups) demonstrated that the recovery rate was significantly higher in the treatment group who received the usual antiviral or antibiotics treatments alone based on the protocol for diagnosis and treatment of novel coronavirus pneumonia (4th edition) or in combination with LH (4 capsules, three times per day) for 14 days, compared with that in the control group (102). Additionally, LH treatment shortened the time to symptom recovery, and improved the recovery of chest radiologic abnormalities with no adverse reactions observed, in comparison with that in the control group (102). Though there were no differences in the rate of conversion to severe cases or viral assay findings, LH capsules may be beneficial in cases of COVID-19, although this requires more randomized, controlled trials in a larger patient population. LH combined with ribavirin, a guanosine nucleoside analog, has been used in the treatment of viral upper respiratory tract infection (103).

Qing Fei Pai Du Tang (QFPDT), a TCM containing 21 herbs, including Ephedra sinica, Bupleurum chinense, Pogostemon cablin, Cinnamomum cassia and Scutellaria baicalensis, is thought to act in the lung $(104,105)$. By regulating a series of proteins co-expressed with ACE2 and signaling pathways closely related to the occurrence and development of diseases, it may play a role in reducing inflammation (104). QFPDT may act as an antiviral agent by targeting ribosomal proteins that are necessary for viral replication, thus inhibiting viral mRNA translation and inhibiting a group of proteins that interact with viral proteins (103). When QFPDT was administered to 214 patients with COVID-19 in China, the majority of patients $(60 \%)$ displayed improved symptoms, where the illness of the $30 \%$ patients were stabilized (106). An additional 701 patients with COVID-19 were treated with QFPDT and, of these, 130 patients (18.5\%) were symptom free after treatment, 51 patients $(7.27 \%)$ recovered from their fever and cough, symptoms were improved in 268 patients $(38.2 \%)$ and stabilized in 212 patients (30.2\%) (106). Administration of QFPDT along with Western medical therapy (the antiviral medicines interferon, lopinavir or arbidol) revealed a tendency to mitigate the extent of multiorgan impairment in 63 patients with confirmed COVID-19 (107), providing evidence that QFPDT combined with antiviral drugs for the treatment of COVID-19 may be beneficial.

Statins. Statins, used conventionally for lowering cholesterol and for their anti-thrombotic properties, also have anti-viral activity $(108,109)$. Statins block the infectivity of enveloped viruses through inhibition of glycoprotein processing. Reiner et al (110) performed docking studies, which revealed that statins interact directly with the main protease enzyme of SARS-CoV-2. Among them, promising statins, including pitavastatin, rosuvastatin, lovastatin and fluvastatin, might be useful in COVID-19 treatment (110). A recent retrospective study involving 13,981 patients with COVID-19 indicated a lower risk for 28-day all-cause mortality in the matched statin group of 1,219 patients, suggesting the safety of statins or the combination of a statin with an angiotensin-converting enzyme (ACE) inhibitor/angiotensin receptor blocker for treatment of patients with COVID-19 (111). As statins may induce the expression of ACE2, resulting in an increased risk of SARS-CoV-2 viral entrance (111), further research is urgently needed to validate the utility of statins to combat the mortality of COVID-19.

Viral main protease $\left(M^{\text {pro }}\right)$ inhibitors. $\mathrm{M}^{\mathrm{pro}}$, a key coronavirus enzyme playing an important role in proteolytic 
maturation (110), has been investigated as a potential protein target to prevent infection expansion (112).

Carmofur (1-hexylcarbamoyl-5-fluorouracil), an antineoplastic agent used to treat colorectal cancer, breast, gastric and bladder cancers, is shown to inhibit the SARS-CoV-2 Mpro. Carmofur inhibits viral replication in SARS-CoV-2 infected Vero E6 cells and shows promise for its successful use as a new antiviral treatment for COVID-19 (113).

Jin et al (114) identified 7 compounds (N3, ebselen, disulfiram, tideglusib, carmofur, shikonin and PX-12) from $>10,000$ compounds, including approved drugs, drug candidates in clinical trials and other pharmacologically active compounds, that could inhibit $\mathbf{M}^{\text {pro }}$. Following further study, ebselen and N3 demonstrated the strongest antiviral effects against SARS-CoV-2. Among these, N3 is a mechanism-based inhibitor developed using computer-aided drug design, which specifically inhibits $\mathbf{M}^{\text {pro }}$ from multiple coronaviruses, including SARS-CoV and MERS-CoV (114). Ebselen is an organoselenium compound with anti-inflammatory, anti-oxidant and cytoprotective properties and has previously been investigated for the treatment of multiple diseases, including bipolar disorder and has a low cytotoxicity (114).

Gupta et al (115) reported that, by using a combination of molecular docking, scoring functions and molecular dynamics simulations, C1 (1E,6E)-1,2,6,7-tetrahydroxy-1,7bis(4-hydroxy-3-methoxyphenyl)hepta-1,6-diene-3,5-dione) and C2 (4Z,6E)-1,5-dihydroxy-1,7-bis(4-hydroxyphenyl) hepta-4,6-dien-3-one, identified from among 267 compounds in Curcuma longa L. (Zingiberaceae family), bound strongly to the catalytic core of the $\mathrm{M}^{\text {pro }}$ protein with higher efficacy than lopinavir, a standard $\mathrm{M}^{\text {pro }}$ inhibitor.

$R B D$-targeting antibodies. As the $\mathrm{S}$ protein plays the most important role in viral attachment, fusion and entry, much of the development of monoclonal antibodies, entry inhibitors and vaccines are focused on the $\mathrm{S}$ protein (28). Specifically, the 193 amino acid length (N318-V510) receptor binding domain (RBD) within the $\mathrm{S}$ protein is a critical target for neutralizing antibodies (116). 206 RBD-specific monoclonal antibodies derived from single B cells of eight SARS-CoV-2 infected individuals displayed potent anti-SARS-CoV-2 neutralization activity but did not cross-react with SARS-CoV or MERS-CoV RBDs (117), suggesting that anti-RBD antibodies are viral species-specific inhibitors. According to a study by Robbiani et al (118), most convalescent plasma collected from individuals who recover from COVID-19 does not contain high levels of neutralizing activity but has anti-SARS-CoV-2 RBD antibodies, suggesting that humans are intrinsically capable of generating potent anti-RBD antibodies that neutralize SARS-CoV-2. In addition, 2 specific human monoclonal antibodies, named CA1 and CB6, from a convalescent COVID-19 patient demonstrated potent in vitro $\mathrm{SARS}-\mathrm{CoV}-2$-specific neutralization activity against SARS-CoV-2 (119).

ACE2-targeting agents. ACE2, identified as an important drug target for the treatment of cardiovascular and kidney diseases, is a key functional receptor for coronavirus infection (120). A fusion protein containing an ACE2 mutant with low catalytic activity, which has a high binding affinity for the receptor-binding domains of SARS-CoV and SARS-CoV-2, has broad neutralizing activity against SARS-CoV and SARS-CoV-2 in vitro and exhibits desirable pharmacological properties in mice (121), suggesting that an ACE2 fusion protein have potential applications in the development of vaccines for SARS-CoV-2 treatment.

Pudilan (PDL), a TCM including Isatis indigotica, Corydalis bungeana, Taraxacum mongolicum and Scutellaria baicalensis has been used as an anti-SARS-CoV-2 agent in China (121). By conducting network pharmacology analysis, PDL might also have therapeutic potential for COVID-19, it may prevent SARS-CoV-2 entry into cells by blocking the ACE2 receptor and by regulating cytokines and chemokines to moderate the immune response (121). However, the targets predicted by bioinformatics and network pharmacology tools require further investigation to confirm.

TMPRSS2 inhibitors. TMPRSS2 facilitates viral particle entry into host cells and its inhibition blocks viral fusion with ACE2 (32). Withanone (Wi-N), a natural compound derived from Withania somnifera and used in Indian Ayurvedic medicine, can bind and stably interact at the catalytic site of TMPRSS2 (122). Having strong interactions with TMPRSS2 catalytic residues, Wi-N may decrease the endogenous expression of TMPRSS2 (122), suggesting that Wi-N probably confers therapeutic effects against COVID-19 by blocking the entry of SARS-CoV-2 into host cells.

TMPRSS2 targets were screened from the natural compounds library Natural Product Activity and Species Source, a freely accessible database containing 30,927 compounds, using a ligand-based pharmacophore approach and a molecular docking-based screen in the Molecular Operating Environment software (123). The 12 compounds with the most favorable structural features were studied for physicochemical and absorption, distribution, metabolism, excretion and toxicity properties. The results suggested that the compound NPC306344, with a low-molecular-weight, interacted significantly with the active site residues of TMPRSS2 (123). However, in vitro and in vivo studies should be conducted to confirm the preventive effect of NPC306344.

Probiotics. Several patients with COVID-19 experienced dysbiosis, characterized by lower levels of Lactobacillus and Bifidobacterium. Prebiotic and probiotic intake for these patients reduces the risk of secondary infection due to bacterial translocation (124), suggesting that probiotics could be a promising strategy for the treatment of SARS-CoV-2.

Scientific data supports the action of probiotics that help maintain or restore the balance of the intestinal microbiome, consequently enhancing the immune response to viral infections, such as SARS-CoV and MERS-CoV, suggesting that probiotics could be beneficial in the treatment of viral infections $(125,126)$. The regulatory role of probiotics on the gut-lung axis and the mucosal immune system for the potential antiviral mechanisms revolves around the competitive inhibition of the growth of pathogenic bacteria. In addition, the secretion of antimicrobial peptides, the action of metabolites, and nucleosidase activity also is responsible for the potential antiviral ability of probiotics $(125,127)$. 
Antibiotics. SARS-CoV-2 infection impairs the host immune system via damaging lymphocytes, especially B cells, T cells and NK cells (128), which may be the main promoter for coinfection with bacteria and fungi $(129,130)$. A single-center, retrospective case series of 221 patients with COVID-19 suggested that the bacterial coinfection rate was $7.7 \%$, and the fungal coinfection rate was $3.2 \%$ (131). A report of postmortem needle autopsy in 10 COVID-19 cases indicated that the pulmonary pathological changes of fatal COVID-19 include signs of diffuse alveolar damage and, in some cases, bacteria and fungi were detected (132), suggesting a serious bacterial or fungal infection secondary to the diffuse alveolar damage. In another 44 nasopharyngeal test samples, 38 varieties of bacteria and 9 varieties of fungi were found (133). A patient with COVID-19 recovered after combination therapy against the virus, bacteria and fungi, and respiratory support. Therefore, antibiotic treatment for COVID-19 patients seemed to be a basic requirement $(130,134)$.

Azithromycin, a macrolide antibiotic with excellent tissue penetration and anti-inflammatory effects, downregulates pathways involving serine proteases TMPRSS2 and TMPRSS11D required for SARS-CoV-2 activation, indicating that azithromycin may hinder SARS-CoV-2 infection (135). In combination with hydroxychloroquine, azithromycin was shown to inhibit the replication of SARS-CoV-2 (136). As of 28th April 2020, there are 21 clinical trials registered on ClinicalTrials.gov for azithromycin related to COVID-19 (137).

However, the most appropriate antibacterial agent must be chosen based on the clinical symptoms of patients with COVID-19 and microbiological results; otherwise, clinicians must halt the misapplication of antibiotics (138).

\section{Vaccines}

According to the latest WHO vaccine candidate research and development report (139), as of 1st October, 2020, there were 187 global COVID-19 vaccines under development, including five known types of vaccine: Inactivated vaccine, attenuated live vaccine, recombinant protein vaccine, nucleic acid vaccine (RNA and DNA vaccine) and virus vector vaccine. Of these vaccines, 38 are in the human trial phase. The progress of vaccine research is summarized in Table I.

Inactivated viral vaccines. Inactivated vaccines use cell culture to create virus particles and destroy pathogenicity, by physical or chemical means, so that the viral particles retain only antigenicity (140). The commonly used cell lines for vaccine production are the canine renal epithelial (MDCK) cells and the African green monkey kidney (Vero) cells (141). A SARS-CoV-2 candidate vaccine PiCoVacc induced a specific neutralizing antibody against SARS-CoV-2 in mice, rats and rhesus monkeys (142), where the inactivated vaccine was safe and reliable. At present, there are nine inactivated vaccine projects. Of these, four are in phase I or II clinical trials. The blind clinical phase III trial of the Vero inactivated vaccine from Sinopharm Group Co., Ltd. has started in Abu Dhabi (143). The results of completed phase I/II suggested that there were no serious adverse reactions in the vaccinated group and that the antibody positive rate reached $100 \%$ according to the 0 and 28-day vaccination procedures. The clinical phase I/II of
CoronaVac inactivated vaccine developed by SinoVac Biotech Ltd. (Beijing Kexing Zhongwei Biological Technology Co., Ltd.) also demonstrated no serious adverse reactions $(144,145)$. The positive conversion rate of neutralizing antibody was $>90 \%$ after 14 days of whole immunization.

Live attenuated viral vaccine. Live attenuated vaccine is obtained by passaging several generations of the virus until it retains only weak pathogenicity in the human host (139). There are three COVID-19 live attenuated vaccine projects under research and development (139): i) A recombinant live attenuated vaccine jointly developed by Codagenix, Inc. and the Serum Institute of India Pvt. Ltd.; ii) a vaccine developed by Griffith University of Australia and India Immunologicals Ltd. (ILL), and iii) the viral vector vaccine and attenuated measles vaccine targeting the $\mathrm{S}$ protein and $\mathrm{N}$ protein developed by the German Center for Infection Research (Deutsches Zentrum für Infektionsforschung) and IDT Biologika GmbH. Due to the long development time of live attenuated vaccine, the three projects have not yet entered the clinical trial stage. Notably, a study suggested that the live attenuated SARS vaccine could produce toxic viral protein again after multiple generations of replication in mice (146), indicating that the live attenuated vaccine still has substantial safety concerns.

Recombinant protein vaccine. The recombinant protein vaccine, a genetically engineered vaccine, is considered to be safe type of vaccine (140). These vaccines are produced by integrating specific antigen viral gene into expression vectors and transforming the expression vectors into bacteria, yeast or animal cells, inducing expression of antigen proteins (140). However, due to the selection of different cells as vectors, the expressed antigen may be different from the natural antigen of the virus, so the immunogenicity is weak (147). There are two methods to solve this problem: Using virus like particles and adding adjuvants (147). A vaccine candidate with M matrix adjuvant of Novavax has entered clinical trial phase II (148). A vaccine developed by Clover Biopharmaceuticals Inc./GSK/Dynavax with an S-trimer, a protein highly similar to the SARS-CoV-2 S, developed using the patented technology of trimer tag and genetic engineering, has been proven to bind to the specific antibody in the serum of convalescent patients (149). A phase I clinical trial was also completed to evaluate the safety and immunogenicity of the S-trimer candidate (149).

Nucleic acid vaccines. Nucleic acid vaccines are also known as gene vaccines, including DNA and mRNA vaccines (150). These vaccines use intramuscular injection of plasmid or naked DNA, RNA or mRNA gene of a certain antigen to induce antigen protein expression in host body, thereby eliciting an immune response $(151,152)$. At present, there are no human nucleic acid vaccines on the market, partially because of some of the technical difficulties in delivering a precise and accurate vaccine. A DNA vaccine may be integrated into the genome because it needs to enter the nucleus to express the antigen (146). Although the mRNA can avoid the risk of host genome integration, it has some disadvantages, such as instability (152). Some methods to improve the stability and protein production of mRNA and to improve the delivery effect have 


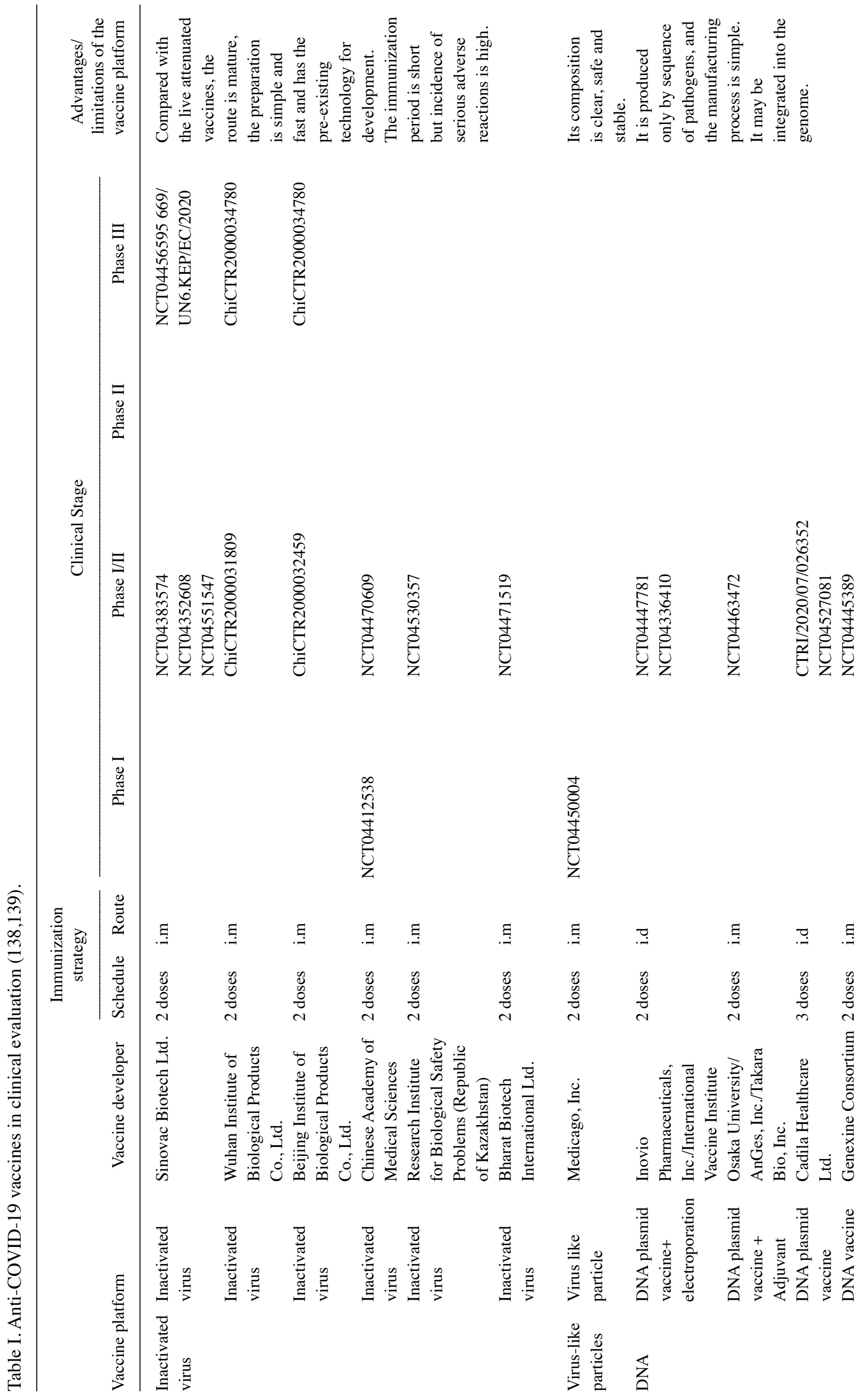




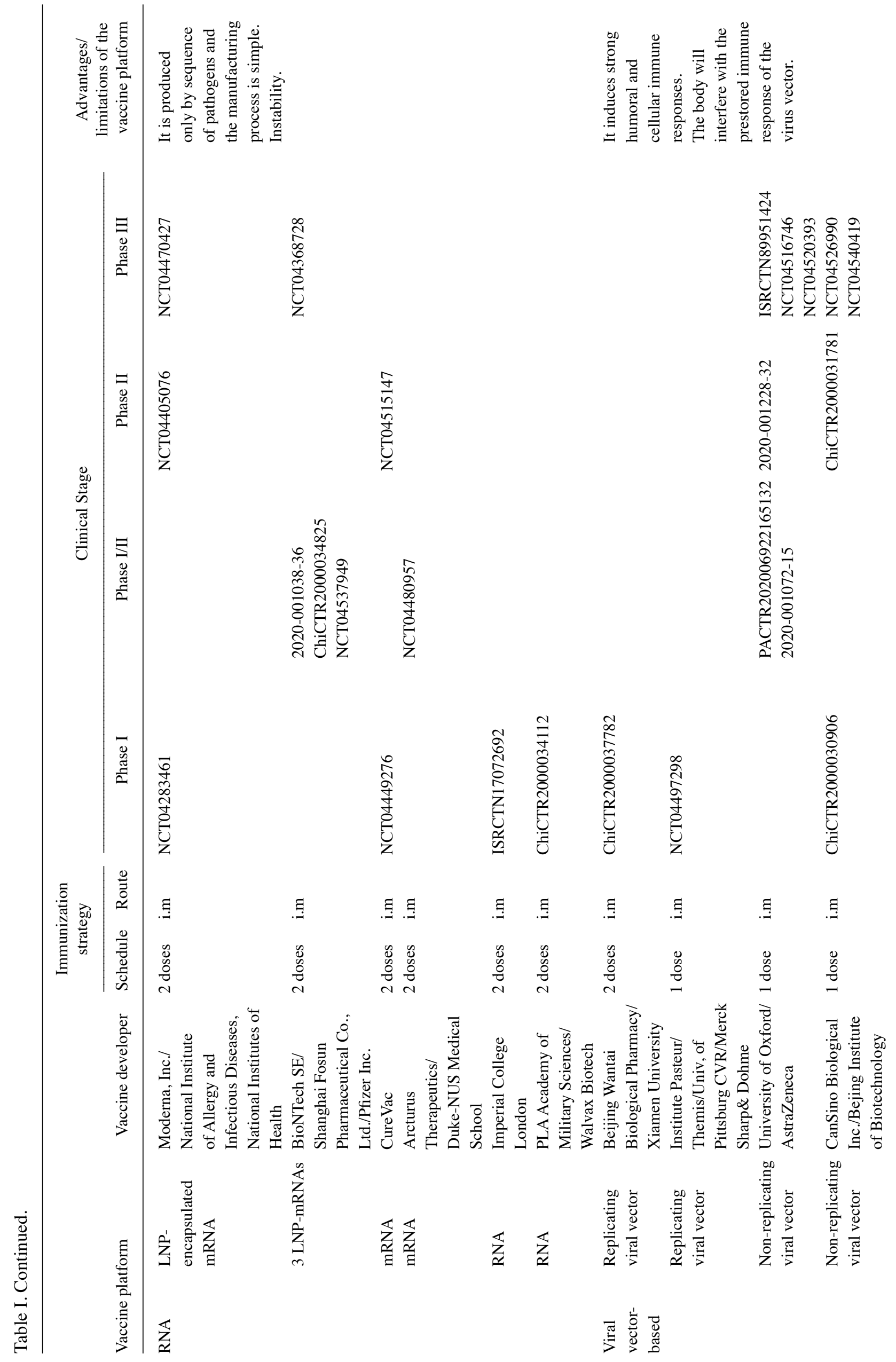




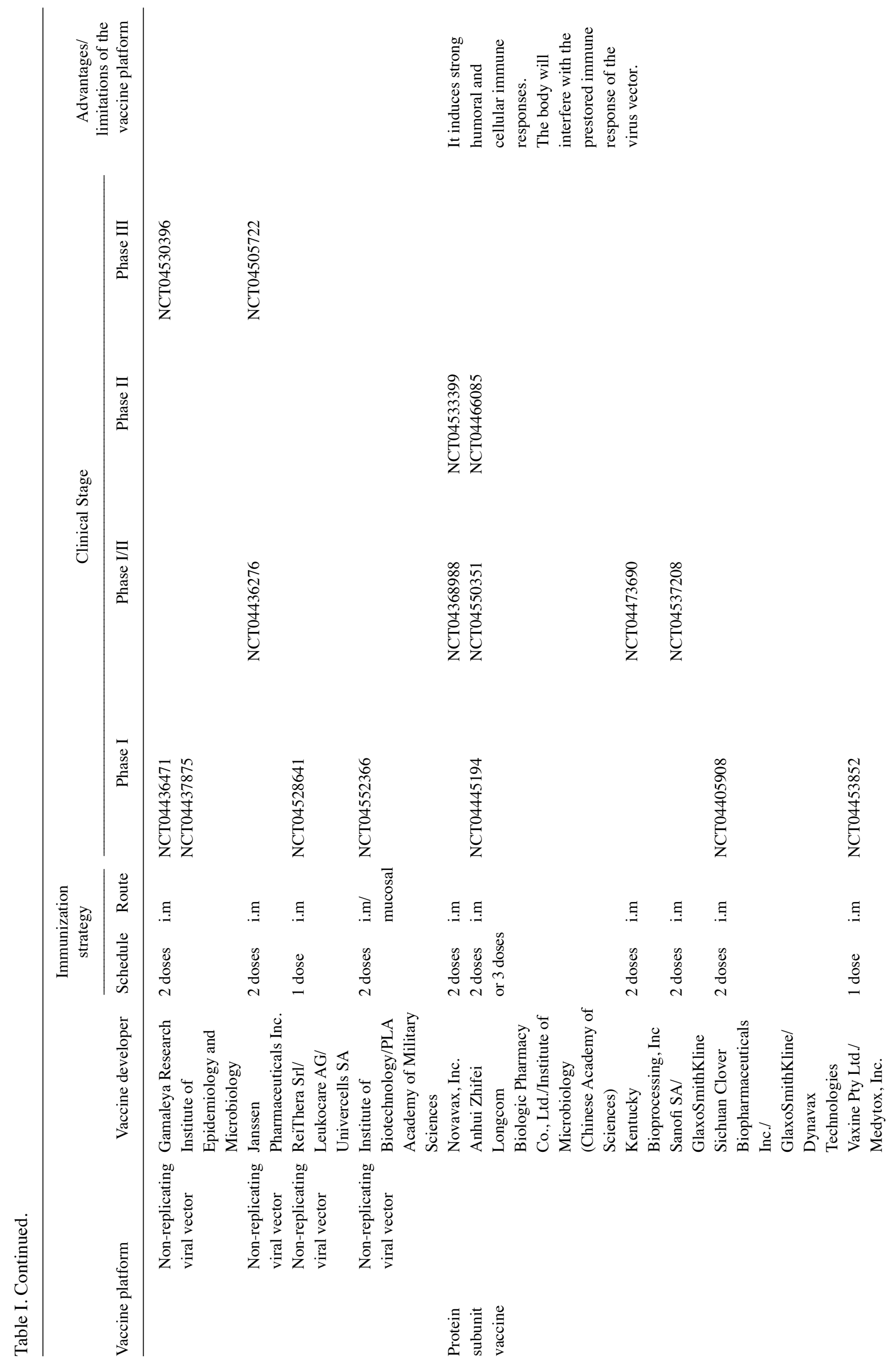




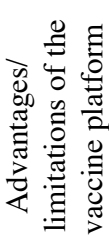

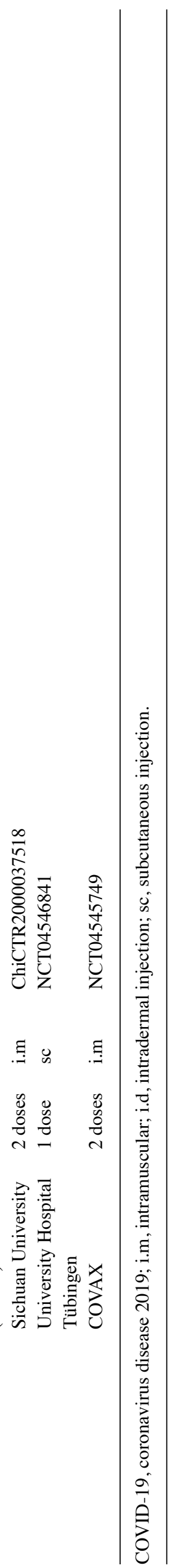


academic focus on an mRNA vaccine (152). These methods include the use of modified nucleotides and the development of nanoparticle delivery systems, which can stabilize mRNA, enhance cell uptake and improve the bioavailability of mRNA after it enters the cell (152).

The first COVID-19 vaccine approved for clinical trial was the mRNA-1273 vaccine developed by Moderna, Inc., which is currently in phase III clinical trials (153). In addition, the mRNA vaccine led by BioNTech SE is in phase III clinical trials (154). Viral vector vaccines. A recombinant virus vector vaccine is a vaccine that takes the replicative activity or non-replicating virus as a carrier and recombines antigenic genes into the viral genome (140). The adenovirus vector (Ad5) vaccine developed by Beijing Institute of Biotechnology and CanSino Biologics, Inc. has entered phase II clinical trials (139). A total of 108 healthy volunteers aged 18-60 were recruited to phase I clinical trials to determine the human tolerance of different doses of the vaccine by observing the safety of vaccine use (155). The results indicated that the Ad5 $\mathrm{NCoV}$ vaccine is well tolerated and can induce an immune response to SARS-CoV-2 (156). Compared with the phase I clinical trials, the phase II clinical trials opened the upper age limit, to further analyze and confirm the preliminary efficacy and safety of the vaccine in the population, and to determine the immune program and dose of the vaccine. In addition, the ChAd0x1-s vector vaccine, led by Oxford University, has also entered phase III of clinical trials (156).

\section{Conclusions and outlook}

SARS-CoV-2 is a new virus and its source, transmission mode, pathogenesis and clinical manifestations are not well-known. In addition, SARS-CoV-2 is highly infectious, creating an outbreak that has spread rapidly to all parts of the world (2). The novel coronavirus has been prevalent all over the world since SARS-CoV-2 was first identified in patients who were exposed at a seafood market in Wuhan City, Hubei Province, China in December 2019 (11). Similar to findings related to SARS-CoV and MERS-CoV, SARS-CoV-2 is believed to have crossed species and initiated primary human infections $(5,6)$. As SARS-CoV-2 will evolve through frequent recombination of its genomes and through mutations (157), the propensity to infect multiple species and the increasing human-animal interface presents unknown problems.

Practicing good hygiene and wearing masks seem to be effective methods to restrict the spread of COVID-19 $(24,158)$. However, prevention and treatment of COVID-19 with drugs remain urgent issues to be resolved. Non-specific antiviral therapy (oseltamivir, ganciclovir), antibacterial therapy (moxifloxacin, ceftriaxone, azithromycin) and glucocorticoid therapy are being improvised by combination with broad-spectrum antivirals such as remdesivir, chloroquine, and lopinavir/ritonavir (159). Plasma therapy shows promise as a beneficial treatment. The deliberate infection of healthy volunteers with SARS-CoV-2 were proposed, as it may shorten the time required for the development of COVID-19 vaccines (160).

During the current outbreak, the development of clinical drugs against coronaviruses has been challenging, and the recent advances in understanding the molecular mechanisms of infection and transmission facilitate more rapid diagnoses and treatment of COVID-19. Aside from traditional drug therapy during the ongoing SARS-CoV-2 epidemic, vigorous efforts on the vaccine development are urgently needed. Finding a short section or sections of viral protein sequence suitable for a synthetic vaccine and antagonists against COVID-19 can be useful for preliminary design proposals. The $\mathrm{S}$ protein, a glycoprotein encoded by coronavirus genome RNA that is usually cut into spherical S1 subunit and rod-shaped S2 subunit during virus assembly, is an important component of coronavirus to recognize and infect host cells. Thus, identification of immunogenic targets against the important SARS-CoV-2 proteins, such as the $\mathrm{S}$ glycoprotein, will provide crucial advances towards the development of sensitive diagnostic tools and potential vaccine candidates. Moreover, the therapeutic options currently under investigation, such as inhibitors targeting the $\mathrm{S}$ protein, require confirmation in clinical trials prior to recommendation. Moving forward there are treatment options available that could be utilized clinically during the ongoing SARS-CoV-2 epidemic, as these agents have shown significant effects against COVID-19 in preclinical trials. Based on knowledge of the mechanism of SARS-CoV-2 replication and infection, a broad-range of combinational therapies should also be evaluated. Computational techniques combined with the mechanistic studies of SARS-CoV-2 can aid in the design and development of predicted antiviral agents. Follow-up experimental studies will test novel candidates for drug repurposing, which will be hopefully be translated into clinical practice.

The present review summarizes the latest findings related to the clinical features, diagnosis, and management of COVID-19. The aim was to provide the most up-to-date understanding of SARS-CoV-2, with ongoing guidance for COVID-19 prevention and control. As there is a dynamic and a large volume of emerging therapeutic approaches for COVID-19, only articles/publications/translations from English (Pubmed database; https://www. ncbi.nlm.nih.gov/) and Chinese (China National Knowledge Infrastructure database; https://www.cnki.net/) of the adult population between December 2019 and September 2020, and realize that some relevant international data might be missing.

\section{Acknowledgements}

Not applicable.

\section{Funding}

This study was supported by grants from the National Natural Science Foundation of China (grant no. 81773271), the Fund of Guangdong Provincial Education Department (grant nos.2017KZDXM088 and 2018KQNCX284), the Joint Basic and Applied Research Fund of Guangdong Province (grant no. 2019A1515110689) and the National Science and Technology Major Project (grant no. 2018YFA0902702). The funders had no role in study design, data collection and analysis, decision to publish or preparation of the manuscript.

\section{Availability of data and materials}

Not Applicable. 


\section{Authors' contributions}

RW prepared the draft manuscript. RW, XL, FL and SL critically revised and edited the manuscript. All authors have read and agreed to the published version of the manuscript.

\section{Ethics approval and consent to participate}

Not applicable.

\section{Patient consent for publication}

Not applicable.

\section{Competing interests}

The authors declare that they have no competing interests.

\section{References}

1. World Health Organization. WHO Director-General's remarks at the media briefing on 2019-nCoV on 11 February 2020. Available from: https://www.who.int/dg/speeches/detail/who-di rector-general-s-remarks-at-the-media-briefing-on-2019-ncov-o n-11-february-2020.

2. Lu H, Stratton CW and Tang YW: Outbreak of pneumonia of unknown etiology in Wuhan, China: The mystery and the miracle. J Med Virol 92: 401-402, 2020.

3. World Health Organization. WHO Director-General's opening remarks at the media briefing on COVID-19-11 March 2020. Available from: https://www.who.int/dg/speeches/ detail/who-director-general-s-opening-remarks-at-the-mediabriefing-on-covid-19-11-march-2020.

4. World Health Organization. WHO Director-General's opening remarks at the media briefing on COVID-19-11 October 2020 Available from: https://www.who.int/docs/default-source/coronaviruse/situation-reports/20201012-weekly-epi-update-9.pdf?sfvr $\mathrm{sn}=49$ dc56e1_4\&download=true.

5. Chan JF, Yuan S, Kok KH, To KK, Chu H, Yang J, Xing F, Liu J, Yip CC, Poon RW, et al: A familial cluster of pneumonia associated with the 2019 novel coronavirus indicating person-to-person transmission: A study of a family cluster. Lancet 395: 514-523, 2020.

6. Li Q, Guan X, Wu P, Wang X, Zhou L, Tong Y, Ren R, Leung KSM, Lau EHY, Wong JY, et al: Early transmission dynamics in Wuhan, China, of novel coronavirus-infected pneumonia. N Engl J Med 382: 1199-1207, 2020.

7. Farsalinos K, Niaura R, Le Houezec J, Barbouni A, Tsatsakis A, Kouretas D, Vantarakis A and Poulas K: Editorial: Nicotine and SARS-CoV-2: COVID-19 may be a disease of the nicotinic cholinergic system. Toxicol Rep 7: 658-663, 2020.

8. Huang C, Wang Y, Li X, Ren L, Zhao J, Hu Y, Zhang L, Fan G, $\mathrm{Xu}$ J, Gu X, et al: Clinical features of patients infected with 2019 novel coronavirusin Wuhan, China. Lancet 395: 497-506, 2020.

9. Ioannidis JPA, Axfors C and Contopoulos-Ioannidis DG: Population-level COVID-19 mortality risk for non-elderly individuals overall and for non-elderly individuals without underlying diseases in pandemic epicenters. Environ Res 188: 109890, 2020.

10. Nasi A, McArdle S, Gaudernack G, Westman G, Melief C, Rockberg J, Arens R, Kouretas D, Sjölin J and Mangsbo S: Reactive oxygen species as an initiator of toxic innate immune responses in retort to SARS-CoV-2 in an ageing population, consider $\mathrm{N}$-acetylcysteine as early therapeutic intervention. Toxicol Rep 7: 768-771, 2020.

11. Zhu N, Zhang D, Wang W, Li X, Yang B, Song J, Zhao X, Huang B, Shi W, Lu R, et al: A novel coronavirus from patients with pneumonia in China, 2019. N Engl J Med 382: 727-733, 2020.

12. Amini Pouya M, Afshani SM, Maghsoudi AS, Hassani S and Mirnia K: Classification of the present pharmaceutical agents based on the possible effective mechanism on the COVID-19 infection. Daru: Jul 30, 2020 (Epub ahead of print). doi: 10.1007/s40199-020-00359-4.
13. Park WB, Kwon NJ, Choi SJ, Kang CK, Choe PG, Kim JY, Yun J, Lee GW, Seong MW, Kim NJ, et al: Virus isolation from the first patient with SARS-CoV-2 in Korea. J Korean Med Sci 35: e84, 2020.

14. Zhou P, Yang XL, Wang XG, Hu B, Zhang L, Zhang W, Si HR, Zhu Y, Li B, Huang CL, et al: A pneumonia outbreak associated with a new coronavirus of probable bat origin. Nature 579: 270-273, 2020.

15. Tian X, Li C, Huang A, Xia S, Lu S, Shi Z, Lu L, Jiang S, Yang Z, Wu Y and Ying T: Potent binding of 2019 novel coronavirus spike protein by a SARS coronavirus-specific human monoclonal antibody. Emerg Microbes Infect 9: 382-385, 2020.

16. Meo SA, Alhowikan AM, Al-Khlaiwi T, Meo IM, Halepoto DM, Iqbal M, Usmani AM, Hajjar W and Ahmed N: Novel coronavirus 2019-nCoV: Prevalence, biological and clinical characteristics comparison with SARS-CoV and MERS-CoV. Eur Rev Med Pharmacol Sci 24: 2012-2019, 2020.

17. Ji W, Wang W, Zhao X, Zai J and Li X: Cross-species transmission of the newly identified coronavirus 2019-nCoV. J Med Virol 92: 433-440, 2020.

18. Wang J, Liang J, Cheng J, Guo Y and Zeng L: Deep learning based image reconstruction algorithm for limited-angle translational computed tomography. PLoS One 15: e0226963, 2020.

19. Sundararaman A, Ray M, Ravindra PV and Halami PM: Role of probiotics to combat viral infections with emphasis on COVID-19. Appl Microbiol Biotechnol 104: 8089-8104, 2020.

20. Wang C, Hornby PW, Hayden FG and Gao GF: A novel coronavirus outbreak of global health concern. Lancet 395: 470-473, 2020.

21. Business Daily: China locks down two cities to curb virus outbreak. Available from: https://www.businessdailyafrica. com/news/world/China-locks-down-two-cities-to-curb-virus-ou tbreak/4259366-5428676-xkv9uo/index.html.

22. Goumenou M, Sarigiannis D, Tsatsakis A, Anesti O, Docea AO, Petrakis D, Tsoukalas D, Kostoff R, Rakitskii V, Spandidos DA, et al: COVID-19 in Northern Italy: An integrative overview of factors possibly influencing the sharp increase of the outbreak (Review). Mol Med Rep 22: 20-32, 2020.

23. Torequl Islam M, Nasiruddin M, Khan IN, Mishra SK, Kudrat-E-Zahan M, Alam Riaz T, Ali ES, Rahman MS, Mubarak MS, Martorell M, et al: A perspective on emerging therapeutic interventions for COVID-19. Front Public Health 8: $281,2020$.

24. Tsatsakis A, Petrakis D, Nikolouzakis TK, Docea AO, Calina D, Vinceti M, Goumenou M,Kostoff RN, Mamoulakis C, Aschner M and Hernández AF: COVID-19, an opportunity to reevaluate the correlation between long-term effects of anthropogenic pollutants on viral epidemic/pandemic events and prevalence. Food Chem Toxicol 141: 111418, 2020.

25. Del Rio C and Malani PN: COVID-19-New insights on a rapidly changing epidemic. JAMA 323: 1339-1340, 2020.

26. Lukassen S, Chua RL, Trefzer T, Kahn NC, Schneider MA, Muley T, Winter H, Meister M, Veith C, Boots AW, et al: SARS-CoV-2 receptor ACE2 and TMPRSS2 are primarily expressed in bronchial transient secretory cells. EMBO J 39: e105114, 2020.

27. Izaguirre G: The proteolytic regulation of virus cell entry by furin and other proprotein convertases. Viruses 11: 837, 2019

28. Kirchdoerfer RN, Cottrell CA, Wang N, Pallesen J, Yassine HM, Turner HL, Corbett KS, Graham BS, McLellan JS and Ward AB: Pre-fusion structure of a human coronavirus spike protein. Nature 531: 118-121, 2016.

29. Li F: Structure, function, and evolution of coronavirus spike proteins. Annu Rev Virol 3: 237-261, 2016.

30. Walls AC, Tortorici MA, Snijder J, Xiong X, Bosch BJ, Rey FA and Veesler D: Tectonic conformational changes of a coronavirus spike glycoprotein promote membrane fusion. Proc Natl Acad Sci USA 114: 11157-11162, 2017.

31. Park JE, Li K, Barlan A, Fehr AR, Perlman S, McCray PB Jr and Gallagher T: Proteolytic processing of Middle East respiratory syndrome coronavirus spikes expands virus tropism. Proc Natl Acad Sci USA 113: 12262-12267, 2016.

32. Hoffmann M, Kleine-Weber H, Schroeder S, Krüger N, Herrler T, Erichsen S, Schiergens TS, Herrler G, Wu NH, Nitsche A, et al: SARS-CoV-2 cell entry depends on ACE2 and TMPRSS2 and is blocked by a clinically proven protease inhibitor. Cell 181: 271-280.e8, 2020.

33. Kawase M, Kataoka M, Shirato K and Matsuyama S: Biochemical analysis of coronavirus spike glycoprotein conformational intermediates during membrane fusion. J Virol 93: e00785-19, 2019.

34. Walls AC, Park YJ, Tortorici MA, Wall A, McGuire AT and Veesler D: Structure, function, and antigenicity of the SARS-CoV-2 spike glycoprotein. Cell 181: 281-292.e6, 2020. 
35. Heurich A, Hofmann-Winkler H, Gierer S, Liepold T, Jahn O and Pohlmann S: TMPRSS2 and ADAM17 cleave ACE2 differentially and only proteolysis by TMPRSS 2 augments entry driven by the severe acute respiratory syndrome coronavirus spike protein. J Virol 88: 1293-1307, 2014.

36. Wrapp D, Wang N, Corbett KS, Goldsmith JA, Hsieh CL, Abiona O, Graham BS and McLellan JS: Cryo-EM structure of the 2019-nCoV spike in the prefusion conformation. Science 367: 1260-1263, 2020.

37. Zhao Y, Zhao Z, Wang Y, Zhou Y, Ma Y and Zuo W: Single-Cell RNA expression profiling of ACE2, the receptor of SARS-CoV-2. Am J Respir Crit Care Med 202: 756-759, 2020.

38. Wang PH and Chen Y: Increasing host cellular receptor-angiotensin-converting enzyme 2(ACE2) expression by coronavirus may facilitate 2019-nCoV infection. bioRxiv: Feb 27, 2020 (Epub ahead of print). doi: https://doi.org/10.1101/2020.02.24.963348.

39. Zhang H, Kang Z, Gong H, Xu D, Wang J, Li Z, Cui X, Xiao J, Meng T, Zhou W, et al: The digestive system is a potential route of 2019-nCov infection: A bioinformatics analysis based on single-cell transcriptomes. bioRxiv: Jan 31, 2020 (Epub ahead of print). doi: https://doi.org/10.1101/2020.01.30.927806.

40. Zu ZY, Jiang MD, Xu PP, Chen W, Ni QQ, Lu GM and Zhang LJ: Coronavirus disease 2019 (COVID-19): A perspective from China. Radiology 296: E15-E25, 2020.

41. Zhang G, Zhang J, Wang B, Zhu X, Wang Q and Qiu S: Analysis of clinical characteristics and laboratory findings of 95 cases of 2019 novel coronavirus pneumonia in Wuhan, China: A retrospective analysis. Respir Res 21: 74, 2020.

42. Tang A, Tong ZD, Wang HL, Dai YX, Li KF, Liu JN, Wu WJ, Yuan C, Yu ML, Li P and Yan JB: Detection of novel coronavirus by RT-PCR in stool specimen from asymptomatic child, China. Emerg Infect Dis 26: 1337-1339, 2020.

43. Corman VM, Landt O, Kaiser M, Molenkamp R, Meijer A, Chu DK, Bleicker T, Brünink S, Schneider J, Schmidt ML, et al: Detection of 2019 novel coronavirus (2019-nCoV) by real-time RT-PCR. Euro Surveill 25: 2000045, 2020.

44. Chu DK, Pan Y, Cheng SM, Hui KP, Krishnan P, Liu Y, Ng DY Wan CKC, Yang P, Wang Q, et al: Molecular diagnosis of a novel coronavirus (2019-nCoV) causing an outbreak of pneumonia. Clin Chem 66: 549-555, 2020.

45. Xiao SY, Wu Y and Liu H: Evolving status of the 2019 novel coronavirus infection: Proposal of conventional serologic assays for disease diagnosis and infection monitoring. J Med Virol 92: 464-467, 2020

46. Tahmasebi S, Khosh E and Esmaeilzadeh A: The outlook for diagnostic purposes of the 2019-novel coronavirus disease. J Cell Physiol 235: 9211-9229, 2020.

47. Liu R, Liu X, Yuan L, Han H, Shereen MA, Zhen J, Niu Z, Li D, Liu F, Wu K, et al: Analysis of adjunctive serological detection to nucleic acid test for severe acute respiratory syndrome coronavirus 2 (SARS-CoV-2) infection diagnosis. Int Immunopharmacol 86: 106746, 2020.

48. Perera RA, Mok CK, Tsang OT, Lv H, Ko RL, Wu NC, Yuan M, Leung WS, Chan JM, Chik TS, et al: Serological assays for severe acute respiratory syndrome coronavirus 2 (SARS-CoV-2), March 2020. Euro Surveill 25: 2000421, 2020.

49. Vieira MA, Vieira CP, Borba AS, Melo MC, Oliveira MS Melo RM, Nunes VV, Santana WS and Aguiar YA: Sequential serological surveys in the early stages of the coronavirus disease epidemic: Limitations and perspectives. Rev Soc Bras Med Trop 53: e20200351, 2020.

50. Wang Q, Du Q, Guo B, Mu D, Lu X, Ma Q, Guo Y, Fang L, Zhang B, Zhang G and Guo X: A method to prevent SARS-CoV-2 IgM false positives in gold immunochromatography and enzyme-linked immunosorbent assays. J Clin Microbiol 58 e00375-20, 2020.

51. Thachil A, Gerber PF, Xiao CT, Huang YW and Opriessnig T: Development and application of an ELISA for the detection of porcine deltacoronavirus IgG antibodies. PLoS One 10: e0124363, 2015.

52. Zhao S, Smits C, Schuurman N, Barnum S, Pusterla N, Kuppeveld FV, Bosch BJ, Maanen KV and Egberink H: Development and validation of a S1 protein-based ELISA for the specific detection of antibodies against equine coronavirus. Viruses 11: 1109, 2019.

53. Sunwoo HH, Palaniyappan A, Ganguly A, Bhatnagar PK, Das D, El-Kadi AO and Suresh MR: Quantitative and sensitive detection of the SARS-CoV spike protein using bispecific monoclonal antibody-based enzyme-linked immunoassay. J Virol Methods 187: 72-78, 2013.
54. He Y, Lu H, Siddiqui P, Zhou Y and Jiang S: Receptor-binding domain of severe acute respiratory syndrome coronavirus spike protein contains multiple conformation-dependent epitopes that induce highly potent neutralizing antibodies. J Immunol 174: 4908-4915, 2005.

55. Lu H: Drug treatment options for the 2019-new coronavirus (2019-nCoV). Biosci Trends 14: 69-71, 2020.

56. Chu CM, Cheng VC, Hung IF, Wong MM, Chan KH, Chan KS, Kao RY, Poon LL, Wong CL, Guan Y, et al: Role of lopinavir/ritonavir in the treatment of SARS: Initial virological and clinical findings. Thorax 59: 252-256, 2004.

57. Chan JF, Yao Y, Yeung ML, Deng W, Bao L, Jia L, Li F, Xiao C, Gao H, Yu P, et al: Treatment with Lopinavir/Ritonavir or Interferon- $\beta 1 \mathrm{~b}$ improves outcome of MERS-CoV infection in a nonhuman primate model of common marmoset. J Infect Dis 212: 1904-1913, 2015.

58. Tu YF, Chien CS, Yarmishyn AA, Lin YY, Luo YH, Lin YT, Lai WY, Yang DM, Chou SJ, Yang YP, et al: A Review of SARS-CoV-2 and the ongoing clinical trials. Int J Mol Sci 21: $2657,2020$.

59. Cao B, Zhang D and Wang C: A trial of lopinavir-ritonavir in covid-19. Reply. N Engl J Med 382: e68, 2020.

60. Warren TK, Jordan R, Lo MK, Ray AS, Mackman RL, Soloveva V, Siegel D, Perron M, Bannister R, Hui HC, et al: Therapeutic efficacy of the small molecule GS-5734 against Ebola virus in rhesus monkeys. Nature 531: 381-385, 2016.

61. Gordon CJ, Tchesnokov EP, Feng JY, Porter DP and Gotte M: The antiviral compound remdesivir potently inhibits RNA-dependent RNA polymerase from Middle East respiratory syndrome coronavirus. J Biol Chem 295: 4773-4779, 2020.

62. Sheahan TP, Sims AC, Graham RL, Menachery VD, Gralinski LE, Case JB, Leist SR, Pyrc K, Feng JY, Trantcheva I, et al: Broad-spectrum antiviral GS-5734 inhibits both epidemic and zoonotic coronaviruses. Sci Transl Med 9: eaal3653, 2017.

63. Martinez MA: Compounds with therapeutic potential against novel respiratory 2019 coronavirus. Antimicrob Agents Chemother 64: e00399-20, 2020

64. Jean SS, Lee PI and Hsueh PR: Treatment options for COVID-19: The reality and challenges. J Microbiol Immunol Infect 53: 436-443, 2020

65. Lo MK, Jordan R, Arvey A, Sudhamsu J, Shrivastava-Ranjan P, Hotard AL, Flint M, McMullan LK, Siegel D, Clarke MO, et al: GS-5734 and its parent nucleoside analog inhibit Filo-, Pneumo-, and Paramyxoviruses. Sci Rep 7: 43395, 2017.

66. Mulangu S, Dodd LE, Davey RT Jr, Tshiani Mbaya O, Proschan M, Mukadi D, Lusakibanza Manzo M, Nzolo D, Tshomba Oloma A, Ibanda A, et al: A randomized, controlled trial of ebola virus disease therapeutics. N Engl J Med 381: 2293-2303, 2019.

67. Brown AJ, Won JJ, Graham RL, Dinnon KH III, Sims AC, Feng JY, Cihlar T, Denison MR, Baric RS and Sheahan TP: Broad spectrum antiviral remdesivir inhibits human endemic and zoonotic deltacoronaviruses with a highly divergent RNA dependent RNA polymerase. Antiviral Res 169: 104541, 2019.

68. Wang M, Cao R, Zhang L, Yang X, Liu J, Xu M, Shi Z, Hu Z, Zhong W and Xiao G: Remdesivir and chloroquine effectively inhibit the recently emerged novel coronavirus $(2019-\mathrm{nCoV})$ in vitro. Cell Res 30: 269-271, 2020.

69. Jordan PC, Stevens SK and Deval J: Nucleosides for the treatment of respiratory RNA virus infections. Antivir Chem Chemother 26: 2040206618764483,2018.

70. de Wit E, Feldmann F, Cronin J, Jordan R, Okumura A, Thomas T, Scott D, Cihlar T and Feldmann H: Prophylactic and therapeutic remdesivir (GS-5734) treatment in the rhesus macaque model of MERS-CoV infection. Proc Natl Acad Sci USA 117: 6771-6776, 2020

71. Holshue ML, DeBolt C, Lindquist S, Lofy KH, Wiesman J, Bruce H, Spitters C, Ericson K, Wilkerson S, Tural A, et al: First Case of 2019 Novel Coronavirus in the United States. N Engl J Med 382: 929-936, 2020.

72. Available from: https://times.hinet.net/mobile/news/22831665.

73. Furuta Y, Komeno T and Nakamura T: Favipiravir (T-705), a broad spectrum inhibitor of viral RNA polymerase. Proc Jpn Acad Ser B Phys Biol Sci 93: 449-463, 2017.

74. Du YX and Chen XP: Favipiravir: Pharmacokinetics and concerns about clinical trials for $2019-\mathrm{nCoV}$ infection. Clin Pharmacol Ther 108: 242-247, 2020.

75. Shannon A, Selisko B, Le N, Huchting J, Touret F, Piorkowski G, Fattorini V, Ferron F, Decroly E, Meier C, et al: Favipiravir strikes the SARS-CoV-2 at its Achilles heel, the RNA polymerase. bioRxiv: May 15, 2020 (Epub ahead of print). doi: $10.1101 / 2020.05 .15 .098731$. 
76. Nagata T, Lefor AK, Hasegawa M and Ishii M: Favipiravir: A new medication for the Ebola virus disease pandemic. Disaster Med Public Health Prep 9: 79-81, 2015.

77. Dong L, Hu S and Gao J: Discovering drugs to treat coronavirus disease 2019 (COVID-19). Drug Discov Ther 14: 58-60, 2020.

78. Korea Biomedical Review. Physicians work out treatment guidelines for coronavirus. 2020. Available from: http://www. koreabiomed.com/news/articleView.html?idxno $=7428$.

79. Notice on Adjusting the Usage and Dosage of Chloroquine Phosphate in Treating COVID-19 Pneumonia. Available from: http://www.nhc.gov.cn/yzygj/s7653p/202002/0293d017621941f 6b2a4890035243730.shtml.

80. Wang D, Hu B, Hu C, Zhu F, Liu X, Zhang J, Wang B, Xiang H, Cheng Z, Xiong Y, et al: Clinical characteristics of 138 hospitalized patients with 2019 novel coronavirus-infected pneumonia in Wuhan, China. JAMA 323: 1061-1069, 2020.

81. Yao X, Ye F, Zhang M, Cui C, Huang B, Niu P, Liu X, Zhao L, Dong $\mathrm{E}$, Song $\mathrm{C}$, et al: In vitro antiviral activity and projection of optimized dosing design of hydroxychloroquine for the treatment of severe acute respiratory syndrome coronavirus 2 (SARS-CoV-2). Clin Infect Dis 71: 732-739, 2020.

82. Liu J, Cao R, Xu M, Wang X, Zhang H, Hu H, Li Y, Hu Z, Zhong $\mathrm{W}$ and Wang M: Hydroxychloroquine, a less toxic derivative of chloroquine, is effective in inhibiting SARS-CoV-2 infection in vitro. Cell Discov 6: 16, 2020.

83. Molina JM, Delaugerre C, Le Goff J, Mela-Lima B, Ponscarme D, Goldwirt $\mathrm{L}$ and de Castro N: No evidence of rapid antiviral clearance or clinical benefit with the combination of hydroxychloroquine and azithromycin in patients with severe COVID-19 infection. Med Mal Infect 50: 384, 2020.

84. Gautret P, Lagier JC, Parola P, Hoang VT, Meddeb L, Mailhe M, Doudier B, Courjon J, Giordanengo V, Vieira VE, et al: Hydroxychloroquine and azithromycin as a treatment of COVID-19: Results of an open-label non-randomized clinical trial. Int J Antimicrob Agents 56: 105949, 2020.

85. Interimclinical guidance forpatients suspected of/confirmed with Covid-19 in Belgium. Availabe from: https://epidemio.wiv-isp. be/ID/Documents/Covid19/COVID-19 InterimGuidelines Treatment_ENG.pdf?fbclid=IwAR2PP0GEhBHm2m3zH7c-.

86. Azioni intraprese per favorire la ricerca e l'accesso ai nuovi farmaci per il trat-tamento del COVID-19. Availabe from: https://www.aifa.gov.it/-/azioni-intraprese-per-favorire-la-ricerc a-e-l-accesso-ai-nuovi-farmaci-per-il-trattamento-del-covid-19.

87. Hoffmann M, Mösbauer K, Hofmann-Winkler H, Kaul A Kleine-Weber H, Krüger N, Gassen NC, Müller MA, Drosten C and Pöhlmann S: Chloroquine does not inhibit infection of human lung cells with SARS-CoV-2. Nature 585: 588-590, 2020

88. Maisonnasse P, Guedj J, Contreras V, Behillil S, Solas C, Marlin R, Naninck T, Pizzorno A, Lemaitre J, Gonçalves A, et al: Hydroxychloroquine use against SARS-CoV-2 infection in non-human primates. Nature 585: 584-587, 2020.

89. Zhang S, Li L, Shen A, Chen Y and Qi Z: Rational use of tocilizumab in the treatment of novel coronavirus pneumonia. Clin Drug Investig 40: 511-518, 2020.

90. Scott LJ: Tocilizumab: A review in rheumatoid arthritis. Drugs 77: 1865-1879, 2017.

91. Venkiteshwaran A: Tocilizumab. MAbs 1: 432-438, 2009.

92. TriestallNews.Coronavirus, will'To-cilizumab'bethedrug of hope? Available from: https://www.triesteallnews.it/2020/03/14/coronavirus-will-tocilizumab-be-the-drug-of-hope/64.

93. Costanzo M, De Giglio MAR and Roviello GN: SARS-CoV-2: Recent reports on antiviral therapies based on lopinavir/ritonavir darunavir/umifenovir, hydroxychloroquine, remdesivir, favipiravir and other drugs for the treatment of the new coronavirus. Curr Med Chem 7: 4536-4541, 2020.

94. Marinella MA: Routine antiemetic prophylaxis with dexamethasone during COVID-19: Should oncologists reconsider? J Oncol Pharm Pract 26: 1482-1485, 2020.

95. Andreakos E, Papadaki M and Serhan CN: Dexamethasone, pro-resolving lipid mediators and resolution of inflammation in COVID-19. Allergy: Sep 21, 2020 (Epub ahead of print). doi: org/10.1111/all.14595.

96. Ledford H: Coronavirus breakthrough: Dexamethasone is first drug shown to save lives. Nature 582: 469, 2020.

97. Shang L, Zhao J, Hu Y, Du R and Cao B: On the use of corticosteroids for 2019-nCoV pneumonia. Lancet 395: 683-684, 2020.

98. Mehta P, McAuley DF, Brown M, Sanchez E, Tattersall RS and Manson JJ; HLH Across Speciality Collaboration, UK: COVID-19: Consider cytokine storm syndromes and immunosuppression. Lancet 395: 1033-1034, 2020.
99. Youssef J, Novosad SA and Winthrop KL: Infection risk and safety of corticosteroid use. Rheum Dis Clin North Am 42: 157-176, ix-x, 2016.

100. Yang Z, Liu J, Zhou Y, Zhao X, Zhao Q and Liu J: The effect of corticosteroid treatment on patients with coronavirus infection: A systematic review and meta-analysis. J Infect 81: e13-e20, 2020.

101. Dong L, Xia JW, Gong Y, Chen Z, Yang HH, Zhang J, He J and Chen XD: Effect of lianhuaqingwen capsules on airway inflammation in patients with acute exacerbation of chronic obstructive pulmonary disease. Evid Based Complement Alternat Med 2014: 637969, 2014.

102. Hu K, Guan WJ, Bi Y, Zhang W, Li L, Zhang B, Liu Q, Song Y, Li X, Duan Z, et al: Efficacy and safety of Lianhuaqingwen capsules, a repurposed Chinese herb, in patients with coronavirus disease 2019: A multicenter, prospective, randomized controlled trial. Phytomedicine: May 16, 2020 (Epub ahead of print) doi: 10.1016/j.phymed.2020.153242.

103. Chen S: Clinical observation of Lianhua Qingwen capsule combined with ribavirin injection in the treatment of viral upper respiratory tract infection. Chin Community Doctors 13: 170, 2011.

104. Zhao J, Tian SS, Yang J, Liu JF and Zhang WD: Investigating mechanism of Qing-Fei-Pai-Du-Tang for treatment of COVID-19 by network pharmacology. Chin Trad Herbal Drugs 4: 829-835, 2020 (In Chinese).

105. Ding Y, Zeng L, Li R, Chen Q, Zhou B, Chen Q, Cheng PL, Yutao W, Zheng J, Yang $Z$ and Zhang F: The Chinese prescription lianhuaqingwen capsule exerts anti-influenza activity through the inhibition of viral propagation and impacts immune function. BMC Complement Altern Med 17: 130, 2017.

106. Yang Y, Islam MS, Wang J, Li Y and Chen X: Traditional Chinese medicine in the treatment of patients infected with 2019-new coronavirus (SARS-CoV-2): A review and perspective. Int J Biol Sci 16: 1708-1717, 2020.

107. Xin S, Cheng X, Zhu B, Liao X, Yang F, Song L, Shi Y, Guan X, Su R, Wang J, et al: Clinical retrospective study on the efficacy of Qingfei Paidu decoction combined with Western medicine for COVID-19 treatment. Biomed Pharmacother 129: 110500, 2020.

108. Yende S, Milbrandt EB, Kellum JA, Kong L, Delude RL, Weissfeld LA and Angus DC: Understanding the potential role of statins in pneumonia and sepsis. Crit Care Med 39: 1871-1878, 2011

109. Chrusciel P, Sahebkar A, Rembek-Wieliczko M, Serban MC, Ursoniu S, Mikhailidis DP, Jones SR, Mosteoru S, Blaha MJ, Martin SS, et al: Impact of statin therapy on plasma adiponectin concentrations: A systematic review and meta-analysis of 43 randomized controlled trial arms. Atherosclerosis 253: 194-208, 2016.

110. Reiner Z, Hatamipour M, Banach M, Pirro M, Al-Rasadi K, Jamialahmadi T, Radenkovic D, Montecucco F and Sahebkar A: Statins and the COVID-19 main protease: In silico evidence on direct interaction. Arch Med Sci 16: 490-496, 2020.

111. Zhang XJ, Qin JJ, Cheng X, Shen L, Zhao YC, Yuan Y, Lei F, Chen MM, Yang H, Bai L, et al: In-Hospital use of statins is associated with a reduced risk of mortality among individuals with COVID-19. Cell Metab 32: 176-187.e4, 2020.

112. Pillaiyar T, Manickam M, Namasivayam V, Hayashi Y and Jung SH: An overview of severe acute respiratory syndrome-coronavirus (SARS-CoV) 3CL protease inhibitors: Peptidomimetics and small molecule chemotherapy. J Med Chem 59: 6595-6628, 2016.

113. Jin Z, Zhao Y, Sun Y, Zhang B, Wang H, Wu Y, Zhu Y, Zhu C, Hu T, Du X, et al: Structural basis for the inhibition of SARS-CoV-2 main protease by antineoplastic drug carmofur. Nat Struct Mol Biol 27: 529-532, 2020.

114. Jin Z, Du X, Xu Y, Deng Y, Liu M, Zhao Y, Zhang B, Li X, Zhang L, Peng C, et al: Structure of M(pro) from SARS-CoV-2 and discovery of its inhibitors. Nature 582: 289-293, 2020.

115. Gupta S, Singh AK, Kushwaha PP, Prajapati KS, Shuaib M, Senapati $S$ and Kumar S: Identification of potential natural inhibitors of SARS-CoV2 main protease by molecular docking and simulation studies. J Biomol Struct Dyn: Jun 11, 2020 (Epub ahead of print). doi: 10.1080/07391102.2020.1776157.

116. Wong SK, Li W, Moore MJ, Choe H and Farzan M: A 193-amino acid fragment of the SARS coronavirus S protein efficiently binds angiotensin-converting enzyme 2. J Biol Chem 279: 3197-3201, 2004.

117. Ju B, Zhang Q, Ge J, Wang R, Sun J, Ge X, Yu J, Shan S, Zhou B, Song S, et al: Human neutralizing antibodies elicited by SARS-CoV-2 infection. Nature 584: 115-119, 2020.

118. Robbiani DF, Gaebler C, Muecksch F, Lorenzi JCC, Wang Z, Cho A, Agudelo M, Barnes CO, Gazumyan A, Finkin S, et al: Convergent antibody responses to SARS-CoV-2 in convalescent individuals. Nature 584: 437-442, 2020. 
119. Shi R, Shan C, Duan X, Chen Z, Liu P, Song J, Song T, Bi X, Han C, Wu L, et al: A human neutralizing antibody targets the receptor binding site of SARS-CoV-2. Nature 584: 120-124, 2020.

120. Lei C, Qian K, Li T, Zhang S, Fu W, Ding M and Hu S: Neutralization of SARS-CoV-2 spike pseudotyped virus by recombinant ACE2-Ig. Nat Commun 11: 2070, 2020.

121. Kong Q, Wu Y, Gu Y, Lv Q, Qi F, Gong S and Chen X: Analysis of the molecular mechanism of Pudilan (PDL) treatment for COVID-19 by network pharmacology tools. Biomed Pharmacother 128: 110316, 2020.

122. Kumar V, Dhanjal JK, Bhargava P, Kaul A, Wang J, Zhang H, Kaul SC, Wadhwa R and Sundar D: Withanone and Withaferin-A are predicted to interact with transmembrane protease serine 2 (TMPRSS2) and block entry of SARS-CoV-2 into cells. J Biomol Struct Dyn: Jun 16, 2020 (Epub ahead of print). doi: 10.1080/073 91102.2020 .1775704 .

123. Rahman N, Basharat Z, Yousuf M, Castaldo G, Rastrelli L and Khan $\mathrm{H}$ : Virtual screening of natural products against type ii transmembrane serine protease (TMPRSS2), the priming agent of coronavirus 2 (SARS-CoV-2). Molecules 25: 2271, 2020.

124. Xu K, Cai H, Shen Y, Ni Q, Chen Y, Hu S, Li J, Wang H, Yu L, Huang H, et al: Management of corona virus disease-19 (COVID-19): The Zhejiang experience. Zhejiang Da Xue Xue Bao Yi Xue Ban 49: 147-157, 2020 (In Chinese).

125. Morais AHA, Passos TS, Maciel BLL and da Silva-Maia JK: Can probiotics and diet promote beneficial immune modulation and purine control in coronavirus infection? Nutrients 12: 1737, 2020.

126. Sharifi-Rad J, Rodrigues CF, Stojanovic-Radic Z, Dimitrijević M, Aleksić A, Neffe-Skocińska K, Zielińska D, Kołożyn-Krajewska D, Salehi B, Milton Prabu S, et al: Probiotics: Versatile bioactive components in promoting human health. Medicina (Kaunas) 56: 433, 2020.

127. Infusino F, Marazzato M, Mancone M, Fedele F, Mastroianni CM, Severino P, Ceccarelli G, Santinelli L, Cavarretta E, Marullo AGM, et al: Diet supplementation, probiotics, and nutraceuticals in SARS-CoV-2 infection: A scoping review. Nutrients 12: 1718, 2020.

128. Wang $\mathrm{M}$, Luo $\mathrm{L}, \mathrm{Bu} \mathrm{H}$ and $\mathrm{Xia} \mathrm{H}$ : One case of coronavirus disease 2019 (COVID-19) in a patient co-infected by HIV with a low CD4+ T-cell count. Int J Infect Dis 96: 148-150, 2020.

129. Luo Y, Xie Y, Zhang W, Lin Q, Tang G, Wu S, Huang M, Yin B, Huang J, Wei W, et al: Combination of lymphocyte number and function in evaluating host immunity. Aging (Albany NY) 11: 12685-12707, 2019.

130. Chen X, Liao B, Cheng L, Peng X, Xu X, Li Y, Hu T, Li J, Zhou X and Ren B: The microbial coinfection in COVID-19. Appl Microbiol Biotechnol 104: 7777-7785, 2020.

131. Zhang G, Hu C, Luo L, Fang F, Chen Y, Li J, Peng Z and Pan H: Clinical features and short-term outcomes of 221 patients with COVID-19 in Wuhan, China. J Clin Virol 127: 104364, 2020.

132. Wu JH, Li X, Huang B, Su H, Li Y, Luo DJ, Chen S, Ma L, Wang SH, Nie $X$ and Peng L: Pathological changes of fatal coronavirus disease 2019 (COVID-19) in the lungs: Report of 10 cases by postmortem needle autopsy. Zhonghua Bing Li Xue Za Zhi 49: 568-575, 2020 (In Chinese).

133. Wang Z, Hu X, Li Z, Tu C, Wang Y, Pang P, Zhang H, Zheng X, Liang Y, Shan H and Liu J: Effect of SARS-CoV-2 infection on the microbial composition of upper airway. Infect Drug Resist 13: 2637-2640, 2020

134. Piva S, Filippini M, Turla F, Cattaneo S, Margola A, De Fulviis S, Nardiello I, Beretta A, Ferrari L, Trotta R, et al: Clinical presentation and initial management critically ill patients with severe acute respiratory syndrome coronavirus 2 (SARS-CoV-2) infection in Brescia, Italy. J Crit Care 58: 29-33, 2020.

135. Renteria AE, Endam Mfuna L, Adam D, Filali-Mouhim A, Maniakas A, Rousseau S, Brochiero E, Gallo S and Desrosiers M: Azithromycin downregulates gene expression of IL-1 $\beta$ and pathways involving TMPRSS2 and TMPRSS11D required by SARS-CoV-2. Am J Respir Cell Mol Biol 63: 707-709, 2020.

136. Fanin A, Calegari J, Beverina A and Tiraboschi S; Gruppo di Autoformazione Metodologica (GrAM): Hydroxychloroquine and azithromycin as a treatment of COVID-19. Intern Emerg Med 15: 841-843, 2020.

137. Parra-Lara LG, Martinez-Arboleda JJ and Rosso F: Azithromycin and SARS-CoV-2 infection: Where we are now and where we are going. J Glob Antimicrob Resist 22: 680-684, 2020.

138. Ardal C, Balasegaram M, Laxminarayan R, McAdams D, Outterson K, Rex JH and Sumpradit N: Antibiotic development-economic, regulatory and societal challenges. Nat Rev Microbiol 18: 267-274, 2020.
139. World Health Organization. Draft landscape of COVID-19 vaccine candidates. Available from: https://www.who. $\mathrm{int} /$ publications/m/item/draft-landscape-of-covid-19-candidatevaccines.

140. Krammer F: SARS-CoV-2 vaccines in development. Nature 586: 516-527, 2020.

141. Bai ZH, Li XR, Wang RB, LIU XR, et al: Review of industrialized production technology of human inactivated vaccine based on mammalian cell culture. Chin J Cell Biol 41: 1986-1993, 2019.

142. Gao Q, Bao L, Mao H, Wang L, Xu K, Yang M, Li Y, Zhu L, Wang N, Lv Z, et al: Development of an inactivated vaccine candidate for SARS-CoV-2. Science 369: 77-81, 2020.

143. World's First Phase III clinical trial of COVID-19 inactivated vaccinebeginsinUAE.Journal2020.Availablefrom:https://www. businesswire.com/news/home/20200717005085/en/.

144. Sinovac. Safety and immunogenicity study of inactivated vaccine for prophylaxis of SARS-CoV-2 infection (COVID-19). 2020-04-20. Available from: https://clinicaltrials. gov/ct2/show/NCT04352608?cond=COVID+vaccine \&draw $=2$.

145. Sinovac. Safety and immunogenicity study of inactivated vaccine for prophylaxis of SARS-CoV-2 infection (COVID-19). 2020-05-12. Available from: https://clinicaltrials. gov/ct2/show/NCT04383574.

146. Wan Y, Shang J, Sun S, Tai W, Chen J, Geng Q, He L, Chen Y, Wu J, Shi Z, et al: Molecular mechanism for antibody-dependent enhancement of coronavirus entry. J Virol 94: e02015-19, 2020.

147. Guo ZY, Liu J and Liu X: Progress in severe acute respiratory syndrome coronavirus 2 vaccine. Chin J Viral Dis 10: 249-254, 2020

148. A Study Looking at the Effectiveness and Safety of a COVID-19 Vaccine in South African Adults. (2020-08-31). Available from: https://clinicaltrials.gov/ct2/show/NCT04533399?term=vaccine \&cond=covid-19\&draw $=7$.

149. Clover Initiates Phase 1 Clinical Trial for COVID-19 Vaccine Candidate. (2020-06-19). Available from: http://www.cloverbiopharma.com/index.php? $\mathrm{m}=$ content $\& \mathrm{c}=$ index $\& \mathrm{a}=$ show $\&$ catid $=1$ $1 \&$ id=48\&langId $=1$.

150. Geall AJ, Mandl CW and Ulmer JB: RNA: The new revolution in nucleic acid vaccines. Semin Immunol 25: 152-159, 2013.

151. Ferraro B, Morrow MP, Hutnick NA, Shin TH, Lucke CE and Weiner DB: Clinical applications of DNA vaccines: Current progress. Clin Infect Dis 53: 296-302, 2011.

152. Mclvor RS: Therapeutic delivery of mRNA: The medium is the message. Mol Ther 19: 822-823, 2011.

153. Moderna Announces Phase 3 COVE Study of mRNA Vaccine Against COVID-19 (mRNA-1273) Begins. (2020-07-27). Available from: https://investors.modernatx. com/news-releases/news-release-details/moderna-announces- $p$ hase-3-cove-study-mrna-vaccine-against-covid.

154. Study to Describe the Safety, Tolerability, Immunogenicity, and Efficacy of RNA Vaccine Candidates Against COVID-19 in Healthy Adults. (2020-09-29). Available from: https://clinicaltrials.gov/ct2/show/NCT04368728.

155. COVID-19 vaccine developed by military medical academy approved for clinical trials. Available from: http://www.chinadaily.com.cn/a/202003/17/WS5e70b732a31012821727fd62.htm.

156. Zhu FC, Li YH, Guan XH, Hou LH, Wang WJ, Li JX, Wu SP, Wang BS, Wang Z, Wang L, et al: Safety, tolerability, and immunogenicity of a recombinant adenovirus type-5 vectored COVID-19 vaccine: A dose-escalation, open-label, non-randomised, first-in-human trial. Lancet 395: 1845-1854, 2020.

157. Li X, Giorgi EE, Marichannegowda MH, Foley B, Xiao C, Kong XP, Chen Y, Gnanakaran S, Korber B and Gao F: Emergence of SARS-CoV-2 through recombination and strong purifying selection. Sci Adv 6: eabb9153, 2020.

158. Han G and Zhou YH: Possibly critical role of wearing masks in general population in controlling COVID-19. J Med Virol: Apr 15, 2020 (Epub ahead of print). doi: 10.1002/jmv.25886.

159. Rabaan AA, Al-Ahmed SH, Sah R, Tiwari R, Yatoo MI, Patel SK, Pathak M, Malik YS, Dhama K, Singh KP, et al: SARS-CoV-2/COVID-19 and advances in developing potential therapeutics and vaccines to counter this emerging pandemic. Ann Clin Microbiol Antimicrob 19: 40, 2020.

160. Calina D, Hartung T, Docea AO, Spandidos DA, Egorov AM, Shtilman MI, Carvalho F and Tsatsakis A: COVID-19 vaccines: Ethical framework concerning human challenge studies. Daru: Aug 27, 2020 (Epub ahead of print). doi: 10.1007/s40199-020-00371-8.

This work is licensed under a Creative Commons Attribution-NonCommercial-NoDerivatives 4.0 International (CC BY-NC-ND 4.0) License. 